\title{
"THE MEANING OF HIS LIFE WAS WORK": THE CONSTRUCTION OF IDENTITIES IN THE ORAL NARRATIVES OF OLDER CZECH MEN
}

\author{
RADMILA ŠVAŘíČKOVÁ SLABÁKOVÁ \\ Palacký University Olomouc, Department of History \\ Křížkovského 10, 77180 Olomouc, Czech Republic \\ radmila.svarickova@upol.cz
}

\begin{abstract}
This article explores the ways in which older Czech men construct their masculine identities. Profiting from the personal memories of individuals who witnessed dramatic social changes in $20^{\text {th }}$ century Czechoslovakia, the study draws on eight oral narratives that focus on the period of older men's youth but also encompass their adult and later lives. The article identifies five recurrent themes through which older men construct their identities and discusses these outcomes in relation to the debate concerning the nature of gender order in the contemporary Czech Republic. It demonstrates the attachment of older men to the patriarchal masculine models of their youth, which are presented as masculine ideals, but also depicts their reservations towards such models. These reservations, however, do not cause older men to argue in favour of greater equality for women.
\end{abstract}

Key words: Czech, gender, identities, masculinity, older men, oral history, $20^{\text {th }}$ century. 


\section{Introduction - A Czech Study of Masculinities}

In spite of a growing interest in the study of gender and gender culture in the countries of the former Eastern Bloc and specifically in the Czech Republic, the majority of research has been devoted to women and to their status both in the past and in the present. Despite the fact that this research perspective has provided scholars with a way to approach problems related to women from an interdisciplinary point of view (see Lenderová 2008 for history; Havelková and Oates-Indruchová 2014; Havelková and Oates-Indruchová 2015a for sociology), far less is known about masculinities in the Czech Lands and in what is currently the Czech Republic. Although one work of particular interest is an extensive recent collective volume on masculinities which includes both historical and sociological texts (Svaříčková Slabáková et al. 2012), the extremely limited sociological research on masculinities demonstrates a preference for the investigation of young men (Šmídová 1999, 2008; Maříková 2007) or focuses on masculinities as affected by state-socialist Czechoslovakia (1948-1989) (Vodochodský 2008; Oates-Indruchová 2006, 2012). The prevalent focus on the era of state socialism can be partially explained by the need to come to terms with the communist past in this country in general and is also up to a point the result of efforts by feminist scholars to challenge the myth of emancipation having been a prime concern of communist leaders (Nečasová 2011, 2014, 2015). According to this myth, which has survived up to the present day, Czech women have long enjoyed equality with men and therefore there was no need to reestablish a feminist discourse after the fall of communism. A new perspective being advocated at present by feminist researchers enables a characterisation of the era of 
state socialism (and primarily the era of late socialism) as a period in which both emancipatory and traditional (patriarchal) discourses of gender relations coexisted. Moreover, emphasising the high moral status of a dissident traditionalist gender discourse, feminist researchers have identified "discursive preconditions for preservation of a strong continual influence of a traditionalist approach towards gender order" (Havelková and OatesIndruchová 2015b: 34). In other words, the specific configuration of gender relations under communism created space for a revival of traditional patriarchal discourse after the fall of communism.

The aim of this article is to contribute to the debate revolving around the issue of a resurrection of patriarchal gender discourse after the fall of communism, particularly focusing on men and their identity formation. As argued by Oates-Indruchová (2015), the era of communism contributed to the expansion of the discursive positions of women (with a slight feminist potential), but masculinities, by contrast, faced the restriction of the discursive positions available to socialist men. In contrast to women who had "traditional femininity as a site of refuge and resistance", the state socialist man had nothing, not even traditional masculinity, to attach to (Oates-Indruchová 2012:377). This "void”, she argues, was caused by the dominant state ideology regarding the representation of men as defenders of socialism. Men therefore had no opportunity to choose their identity but were forced into uniformity by identification with the labour force, with socialist citizenship and with their mission as "soldiers and defenders of the country" (Oates-Indruchová 2006).

While Oates-Indruchová draws on an analysis of narrative fiction for her study, research outcomes reported by Ivan Vodochodský (2008) based on the biographical experiences of men born in Czechoslovakia in the 1940s 
have shown a similar picture. Vodochodský also observed the obvious absence of a positive masculine script for the current lives of men in the first decade of the $21^{\text {st }}$ century (an intellectual who emigrated and returned after 1989 could fill the role, states the author, but this was the case with only an extremely limited number of men) and the need for the participants to construct their biographical narratives. This was not necessarily explicit but also seen in relation to such an ideal subject, someone who was able to "fight against the regime and follow his truth even at the cost of imprisonment, emigration or a threat to his own family" (Vodochodský 2008:148).

\section{Research aims}

The question of interest in this article is the position of men who were born and lived not only during the era of state socialism but also before and after it. Will these men, who were born in the radically different social-political conditions of the period preceding state socialism, in other words the 1920s and 1930s, also have difficulties in positioning themselves towards positive masculine scripts? Will these men also suffer from the "void" of an acceptable masculinity? In general terms, how will these men compose their stories and how could such an act of composition be related to their masculine identities?

As my method of inquiry, I have chosen oral history, understood not merely as a method for gathering data, but as "an active process of creation of meanings" (Portelli 2003: 69) through the recounting of life stories. People not only remember what happened to them, but also provide meaning for their past recollections by interpreting them. By retelling stories about themselves, they define who they are (Fivush 2008) and inevitably 
construct themselves in terms of gender relations. If masculinity is not something we have or have been born in, but rather something "constructed in and through discourse" (Edley 2001:191), oral narratives provide a perfect terrain for exploring a construction of masculine identity.

\subsection{Methodology}

I draw on eight oral narratives for my research. This sample of eight interviews may seem very limited in terms of research value, but given the subjects of the study (older men of an advanced age) and the chosen method of analysis, the small number of interviews does not invalidate the outcomes. This rather small sample of interviews is also in line with the views of John W. Creswell, who argues that it is normal within qualitative research to study just a few individuals or a few cases (Creswell 2011:209).

The choice of narrators was based on the age of the participants and, obviously, on their health. They had to be at least 80 years of age to be able to talk about their life during the First Czechoslovak Republic and had to be people living in their own homes and taking care of themselves. The initial difficulties of accessing potential participants were eliminated by the employment of a direct access strategy towards them. Six of the men were approached personally face-to-face and another two were recommended by relatives.

The choice of locale was limited to the region in which I live. It is a medium-sized town (50,000 inhabitants) in the Highlands with a markedly rural hinterland. The interviews took place over the course of two years, 2010 and 2011. All the interviewees were born within a period slightly longer than a decade - the oldest man in 1916, the youngest in 1928. Each participant was interviewed once. The interviews lasted from 45 to 80 
minutes, depending on the health of the participants, given that the oldest man was 94 years old, the youngest 83 . The interviews were tape-recorded and subsequently fully transcribed for analysis. Lengthy extracts have been translated into English and used in this article.

It is important to add that half of the participants had had only primary education, three had had secondary school education and only one narrator had had a university education. Five of the participants came from rural backgrounds (although not all remained in agricultural jobs throughout their lives) and three were born in an urban setting. Three of the participants were widowers still living in their houses with the families of one of their children, one lived with a female friend, and the rest still lived with their partners. The interviews were held in the participants' homes.

The interviews had two parts. In the first part of the interview, the participants were asked to provide memories of their childhood and youth. They were encouraged to tell their own story, without the intervention of the interviewer. Already at this stage, the interviewed men deliberately moved on to recount their subsequent lives, with the majority of them talking about their entire lives. In the second part, all the interviewees were asked the same questions if these had not been answered earlier in their narration: about their father and mother, their spouse, and their image of an ideal man and woman. The aim of these questions was to raise some gender-relevant issues, that is, in the private sphere, but only to the extent that the general direction of the talk remained in the hands of the men being interviewed. The analysis stage consisted of repeated reading of the fully transcribed interviews. I was particularly interested in the way older men constructed their identity. Which episodes and which events were important for them to recount? What do such memories tell us about their masculine identity? 
During a repeated reading of the transcribed interviews, I found that the interviewed men tended to focus their memories on four themes - their relationship with other men, mainly fathers and grandfathers, their relationship to work, particularly hard physical labour, their relationship to physical capacity and physical strength, and their relationship to women, mainly mothers and spouses. I present these four themes below as aspects of the interviewed men's identities. Although the aim of this analysis is not to dwell on intersubjectivities in the process of the interviews conducted, the fifth point has been added to demonstrate how identity can be negotiated in the interview process on the level of different gender models. I have made use of the participants' own words to introduce each aspect and these words are also intended to reflect the content of the aspect. In order to protect the participants' anonymity, pseudonyms have been used in place of real names.

\subsection{Specificities of oral history methodology}

While there are multiple ways to analyse a narrative, as has recently been magnificently documented by Spector-Mersel (2014), the process appears to be more complicated when one wishes to analyse a narrative about a distant past produced in the present. The narrators discuss their experience in the first half of the $20^{\text {th }}$ century but with their experience of the world of the $21^{\text {st }}$ century. They recount their experience of being young men within the patriarchal gender order of the 1920s and 1930s but with the experience of gender relations today. The past and present are inseparable in this respect. Even if the narrations focused initially on the period of the participants' youth, subsequent experience tended to penetrate into the participants' talk. As has been advanced by oral history researchers (Summerfield 2004, Abrams 2010:46-48), the authenticity of the experience 
is overlapped by subsequent discourses and interpretations to the extent that it is "impossible for anyone to remember what they did and what they thought at the time independently of this 'patina of historical postscripts and rewritings"" (Summerfield 2004:66). The recollections of the narrators are rather reconstructions of the past than "windows onto reality". However threatening this claim may be for historians whose task is said to be to describe "how things actually were", the constructivist position allows for a focus on men's identity construction regardless of whether they are discussing the period of their youth or later periods. Consequently, in this article I do not focus exclusively on the description of the patriarchal gender order in the First Czechoslovak Republic but instead concentrate on the ways the older men recounted their stories in relation to their life-long experience. Identity is created during the interviews, but not independently of larger gender structures which the participants were aware of when discussing their childhood, youth and subsequent lives.

\subsubsection{Older men's constructions of identities - The First Aspect}

"My father and I" (Pavel): Relationships with other men, mainly fathers and grandfathers

The first aspect on which the interviewed men drew on for their identity construction is the fact that the majority of respondents were only able to handle the interview process after having associated their past with other men, specifically their fathers and grandfathers. They began the discussion by describing their fathers' professions, their fathers' jobs. They also remembered the time they spent with their fathers and grandfathers and

\footnotetext{
${ }^{1}$ According to Leopold von Ranke, a father of modern history, the historian must describe
} 
provided a more detailed description of it. Mothers, although traditionally associated with small children, appeared to be almost non-existent in the participants' recollections and, if they were mentioned, it was in a rather casual, informal way. The impression was that the participants experienced difficulties remembering concrete facts about their relationship with their mothers during their youth. Not only were the masculine personalities and their carriers presented as decisive for the narrators' identity formation, but their fathers' jobs also structured the participants' recollections, as is depicted in Mojmir's account:

\footnotetext{
My parents built a house with my mother's parents and my grandfather did the farming there. He had a small farm, three cows and a six hectare field, so I grew up with my grandpa. He always took me to the field, put me for instance on a blanket and ploughed. And then, he put me a bit further, this way [showing with his hands how his grandfather picked him up and moved him a little bit further]. My youth was a farming one.
}

Not all fathers and grandfathers, however, were presented by the participants as masculine role models. Reservations were observed in cases where the participants' fathers did not correspond to the generally accepted hegemonic masculine pattern of the period. Hegemonic masculinity, understood for the purpose of this article as a "culturally exalted pattern of masculinity" (Connell 1995:77), was associated, in the period of the participants' youth, with strength, endurance, bravery, activity and selfconfidence (Lenderová 2012:238). If masculinities are multiple and variable, the participants referred exclusively to their hegemonic form and rejected any other forms. 
The fathers who served as role models for the participants were "good persons", "good farmers". The narrators valued above all the fact that their fathers were hard-working, that they perfectly understood their jobs (mainly farming) and were experts at it. Joseph, for instance, described in detail how his father used to walk barefoot in the stubble field. He admired him as a child. The masculine image of death, excluding all feminine attributes such as weakness and illness, was another source of esteem: "My father died in bed with a pipe in his mouth. I'll never forget it."

Reservations towards their fathers' masculinities were observed in three cases: such a father could have been seriously physically injured which prevented him from working, unemployed, or heavily dependent on wage labour and therefore poor. The participants presented the masculinity of such fathers as threatening for them and delimited themselves from such models, as depicted in the following extract by David:

I did not admire anything about him... There was no work, so he was at home. He cooked and my mother sewed aprons. And when he finished cooking, he left to go and talk somewhere. And mother had to sew until she had completed ten aprons.

There was nothing to respect about the behaviour of this father, who was unemployed in the period of the economic crises. Unemployment and cooking, a woman's job, were not the activities of a man worthy of his son's respect.

A notable feature is that the participants constructed their identity in relation not only to the masculinity of their fathers but also in relation to current masculine models. They frequently compared their situation as boys with that of today's generation of boys. The narrators emphasised their own 
persistence and discipline and criticised the weakness of today's boys. The account by David illustrates this position:

I say today that these brats are so spoiled that it is terrible. No discipline. It is bad. ... before each boy had his duties... before the boys were independent. Not like today, they are led by hand, it did not use to be like that. There was only work. You have to do this, you have to arrange that, this is your duty. So, that's what we did.

Hard-working rural fathers and grandfathers were described as masculine models for the participants. Such a model was built on discipline, obedience and the physical capacity to cope with hard work (or other difficult conditions), the qualities which they describe as lacking among the present generation of boys.

The participants seemingly point to different masculine models available to the current generation of boys and disagree with them. As documented by feminist researchers (Wagnerová 1995, Havelková 1999), under communism the paternalistic state took over the roles previously held by men (particularly their role as breadwinners) and deprived them of key aspects of traditional masculinity. Due to the nationalisation of private property, men lost their independence, and the low wages forced women to seek employment too so that the family could survive; men's power and status diminished significantly. The concept of the "void of acceptable masculinity" advanced by Libora Oates-Indruchová offers another explanation for the lower status of men under state socialism. The masculinities ideologically supported by the communist state, such as defenders of socialism or workers in factories, were not, according to the author, accepted by men, and other positive representations of masculinity were absent (Oates-Indruchová 2006, 2012). 
After the fall of communism, the most likely candidates to fill the "void" were either the new man of the 1980s, or Connell's hegemonic transnational business masculinity (Connell 2000, cited in Oates-Indruchová 2012:378).

Oates-Indruchová (2012) also, however, advances the idea of the potential of a residual patriarchal discourse to become dominant again after 1989. It is my opinion that the older men, in their narratives about their fathers, were relating to this version of patriarchal discourse, highlighting positive masculine models which came from the period of their youth and were therefore not discredited by the communist regime.

The first aspect is notable for its explicit relation to other men, particularly the participants' fathers and grandfathers. The narrators nevertheless expressed their attachment to only those men who conformed to certain models of masculinity of the period. Men who could not act in a manly way, including those who did "women's jobs" and who could not work "hard", did not represent a suitable masculinity for the participants to emulate. In this way, the accounts of the interviewed men address the dominant masculine ideology of the 1920s and 1930s, at least that prevailing in rural areas.

\subsubsection{The Second Aspect}

"In the morning, to wake up at five o'clock, and to work till the evening, including Saturdays." (Bohuslav): the relationship to work, particularly hard physical labour

The second aspect revolves around physical labour being part of the masculine world. The interviewed men attributed this kind of work to their fathers (grandfathers) and to themselves when evoking their childhood and youth. The theme of work, however, pervaded their talk. Jobs and work of 
various kinds formed the backbone of each participant's narrative. For some, work was the only topic they could discuss in detail; for others, work functioned as the most important issue in their lives.

The work the participants referred to most often was hard physical labour and, above all, rural labour. All the interviewees with a rural background emphasised how hard and tough the work of their fathers and themselves was. They talked at length about the need for physical strength to do such work. Peter explained: "I was 14 and I would cut (with a scythe), I was among the mowers, you know? And they were the men, you know? They were strong."

The position of hard rural labour, however, as a source of positive identification for the participants' masculinities changed over the course of the lives of the interviewees. Beginning with 1948, the year of the communist seizure of power, social conditions in the countryside, practically unchanged hitherto, even during the Second World War, were dramatically altered. Collectivisation liquidated large independent farmers and possession of land above 50 ha per family was forbidden. Many of the large landowners were deported and other smaller ones were forced to join agriculture cooperatives. The obligation of independent farmers to subsidise the state with part of their yearly production, a part which constantly increased, was considered a kind of direct persecution and the means by which independent farming was largely destroyed (Rokosová 2003).

The participants, coming as they did from traditional farming families, reflected on the long, difficult struggle against collectivisation in their narrations, as demonstrated by Petr's words:

They made the subsidies larger and larger and it was hard to fulfill it then. Then it came, they were persuading us to enter the cooperatives. Some refused, some went 
of their own accord. For us, it was a liberation, because we were not able to manage. Saturdays, Sundays, we were not aware of their existence. If there was a need, we had to go.

At the end of the 1960s, practically all the remaining independent farmers joined the cooperative farms as employees or escaped to towns. Formerly independent farmers found themselves in a completely different power situation.

In his assessment of his behavior at the time, Petr is uncompromising: "We worked like dogs", "we laboured and we had nothing from it". In response to the devaluation of the labour of independent farmers (the value was transferred to collectivised farmers or to factory workers), the respondents highlighted their persistence and the difficulty of such work and expressed, once again, their doubts concerning the ability of the younger generation to survive similar conditions.

Due to collectivisation and nationalisation, the masculinity of the generation of the participants' rural fathers not only lost its attractiveness but was entirely liquidated. New protagonists of power in the villages, an appointed communist official or the chairman of a national committee, could not replace the natural authority of a major village farmer from a long-term settled family. The participants distanced themselves from the new masculine models established in their villages.

You know, there always came some chairman, some total unknown. A man known by nobody and he was the chairman, can you imagine? ... These men were very bad, very bad. (Petr) 
Because of a lack of coherent data related to the participants' lives under communism, we can only hypothesise about their rejection of the masculine models offered by the state ideology (see the preceding section). Such rejections of ideologically supported masculinities have already been confirmed by other research, as described earlier (Vodochodský 2008).

In general, all the participants highlighted their ability to work, to do something right, to achieve a particular position in their career or to be able to accomplish a task that nobody else had been able to do. Petr emphasised that he could repair things that "nobody in the house was able to repair", even in his old age. Joseph passionately recalled how he managed to "put everything in order" when he joined the cooperative and was made the head of a working group since "such disorder" had prevailed there prior to his joining. Bohuslav insisted on showing his interviewer "vopalky", local hand-woven baskets, as well as the production process, which he had learned on his own during his childhood without any help from his father and which he practises to this day.

The men's connection to the masculine patterns of their youth was highlighted in their references to retirement. David openly commented on his emotions once he heard the news: "I was in some way disappointed; everybody is accustomed to some work and now, suddenly, I was told: Tomorrow you finish." He went on to explain his conscious rejection of masculine patterns which he saw as traditionally considered suitable for retired people: "And that is what I need, to work. To be in charge of something. If I see, those, listen to those... those men, they talk only about illnesses. And I hate it." His ambivalent position towards "those", whom he is reluctant to call "men", indicates his willingness to hold on to a masculine identity of a tough, hard worker shaped in the period of his youth. 
The second theme presented hard-working rural fathers as the masculinities our narrators had identified with. The common feature is the difficulty and the arduousness of their rural toil, which is not comparable to any of today's work. Even in later periods, the participants expressed their willingness to conform to the masculine models of their youth and to hold on to "work" and their ability to work (to do something well) as a sign of their manliness.

\subsubsection{The Third Aspect}

"I used to represent my town in the long jump and the high jump" (Jan): the relationship to physical capacity and physical strength

It is a striking fact that those men who did not come from a rural background and could not therefore speak about hard rural labour in their childhood and youth, instead emphasised various sporting activities performed during their youth. These activities were described as natural for the participants, as something boys should do. They are worthy of reference in the early parts of the discussion, as in the case of Mojmir:

When I was five, I started to exercise at the Sokol gym [a famous Slav gymnastic society] and I did exercise actively up to the age of 36. I played football and ice hockey in competitions... I represented Prague secondary schools.

Not surprisingly, images of physically strong men were also provided for the periods of the men's adult lives. Bohuslav, for example, spoke animatedly about walking several kilometres every day to the factory where he worked. The others shared descriptions of the extensive sporting activities in which they excelled, as was the case with Mojmir above. 
Vaclav, after having mentioned his active hiking activity up until recently, described in detail his experience as a mountain climber.

I was an active mountain climber. I had a second performance status, so I had 14 days of practice in the High Tatras for free. So I always went when I had this status, the status of a mountain climber. It was quite demanding... and then I began to do canoeing ... So I made a canoe trip to Zelezna vrata [a dam called 'the Iron Gate']. It is on the Danube River. And we went from Bratislava, can you imagine? It was a very hard three-week trip. And I did it once more. It was terrible. My wife was with me, she put up with an awful lot. I cannot imagine why I put her through such difficult things.

Sporting activities accompanied by demanding physical effort were presented as a feature of true masculinity, even during the adult lives of the participants. If sport is considered "a central experience of the school years for many boys" (Connell 1983:13), in the particular circumstances of the communist regime, sports and games were viewed as the only compensation for the loss of key aspects of traditional masculinity (Havelková 1999, Šmídová 1999) which was referred to in previous sections.

A notable feature of the interviewed men's discussion of sporting activities, found also in their descriptions of their work activities, is the emphasis on their ability to do these activities well. Mojmir was one of the "good sportsmen" who could do circles on the horizontal bar, something which contributed to attracting his wife. He was a "sports type, in shorts all the time". Jan learned to play chess "quite early", Pavel loved horses and passionately described the way he would ride a horse around their fields.

Analysing the discussion of his participants, Vodochodský (2008) found that in spite of a complicated negotiation identity process, there was a hegemonic masculinity common to all of his interviewees (men born one 
generation later than our participants). He termed this kind of masculinity the "masculinity of a good craftsman". Our participants might also have subscribed to this kind of masculinity, as expressed by Mojmir:

An ideal man has to be skilful, not be silly, and make an effort to achieve something in the world, so that he means something. I wanted to be such a man and I managed to do so.

Another particular point of this section is the participants' construction of masculinity in relation to aggression. While usually associated with a hegemonic masculinity (Connell and Messerschmidt 2005), aggression is almost absent from the content of the discussions and the participants did not use, even verbally, any aggressive expressions. Surprisingly, although all the participants described their upbringing as firm and strict, they did not speak of much experience of corporal punishment. If they were slapped by their fathers, this did not happen often - once or twice at most. I would suggest two explanations for this, coming from two temporally different masculine models available to the participants for their constructions of masculinities. The first model relates to a Central European Biedermeier (middle-class) tradition which idealised the institution of fatherhood (Filipowicz and Królak 2008). In this tradition, loving and ideal fathers acted as heads of the family; there was nothing similar to the Victorian model of an "unsmiling domestic tyrant", the most negative stereotype of fatherhood identified by John Tosh (2005:129). The second explanation relates to a rejection of macho masculinity, traditionally associated with the working-class (Tolson 1987), by the communist regime. Macho-class masculinity, marked by verbal and physical violence, was, according to the analysis of narrative fiction under state socialism carried out by Oates- 
Indruchová (2012), associated exclusively with the underworld and the prison environment. With this macho version rejected as unsuitable for a socialist subject, it was a traditional middle-class masculinity (a bourgeois version of Connell's hegemonic masculinity - Oates-Indruchová 2012:365) which was ideologically hegemonic during the period of state socialism. This middle-class masculinity, which had to serve as a correct pattern of behaviour, was transferred, however, to the working-class (the middle-class was associated with the bourgeoisie, the enemy of the communist regime). This former middle-class and now ideologically supported working-class masculinity was defined by "competitiveness, personal ambition, social responsibility and emotional restraint" (Tolson 1987:39, quoted in OatesIndruchová 2012:365), and was related to work, achievement and moral integrity.

In their construction of masculinities, the interviewed men could, therefore, draw on both models. One had originated in the $19^{\text {th }}$ century Biedermeier tradition, while the second was linked to the condemnation of traditional macho-masculinity by the communist regime. Aggression being absent from both models, the participants constructed their masculinities as softer and morally integrated, corresponding to the requirements of middleclass masculinity (although the majority of the participants came from a rural background).

The third aspect is notable for the construction of the men's identities in relation to sport and physical activities. These activities are presented as natural for boys and the emphasis is placed on the abilities of the interviewed men to excel at them. This aspect also relates to middle-class masculinity, considered as ideologically hegemonic during the era of state 
socialism and marked by an absence of the violence traditionally associated with macho-masculinity.

3.2.4. The Fourth Aspect "Our mother was amazingly caring" (Mojmir): the relationship to women, particularly mothers and spouses

The fourth aspect is based on the assumption that the identity of a particular social subject can be expressed by his relationship to the "others": "we" use the "others" to define ourselves (Wilkinson and Kitzinger 1996:8). The participants in this case described women, particularly their mothers and wives, including their activities, and in contrast to them expressed their own identity.

As stated above, the participants rarely talked about their mothers unprompted. Asked by the interviewer, however, the participants offered images of mothers that corresponded to the ideal of womanhood prevailing in the $19^{\text {th }}$ century: a dutiful caregiver and a submissive housewife. The adjectives used for the descriptions of their mothers ranged from "caring", through "self-sacrificing", "tiny", "smaller", "weak" to the allencompassing "poor thing". The depictions of their mothers were the exact opposites of the portrayals of their strong, if hard physical work was performed, fathers and grandfathers. Not only was the distribution of gender roles placed within a breadwinner and homemaker dichotomy, but the qualities attributed to women also corresponded to the stereotyped dichotomies consolidated during the $19^{\text {th }}$ century: strong/weak, mighty/small, hard-working/care-giving. 
An interesting fact is that when discussing their mothers' work activities, the participants used the word "help", as can be illustrated from the words of Vaclav:

My grandmother was a typical Viennese girl. She followed my grandfather. My grandfather brought her here. And my grandmother also helped in a tailor's workshop when there was a lot of work. ... She helped there. She sewed something there, I don't know what exactly.

Apparently, the duty of Vaclav's grandmother, who spent her life in the household, was not only to look after the house, but also to "help" her husband if there was a need. Of interest here is the lower status of her work; it was only "help", not work worthy of the name. The fact that the grandmother helped her husband is presented as natural by the participant, as is the fact that she followed him to her new home. The role of women as helpmates of their husbands extended, in this participant's discussion, over three generations: his mother helped his father in the shop and his wife helped the interviewed man during his sporting activities when she accompanied him and cooked for him.

Although the narrators presented their mothers as caring and selfsacrificing creatures, when asked to provide more details, they also depicted their mothers' diligence in work and ability to cope with all their duties. Thus mothers ended up appearing to be much more resilient and autonomous than the stereotyped image of traditional motherhood initially advanced by the participants could have conveyed.

In contrast to their fathers, who were in certain cases depicted as failing to serve as adequate masculine models for their sons, the participants' mothers presented in all cases a correct model of femininity. 
The interviewed men valued their self-sacrifice and their ability to work hard, to do everything in the household and to be an understanding and faithful wife. The same qualities were attributed by the participants to their own wives, in contrast, again, to the young women of today's generation:

My wife came, she knew everything, everything about sewing, about cooking or anything, it was no problem. My wife sewed overalls for kids, they were sold for a huge amount at that time. This kind of wife cannot be lazy like they are today. (Mojmir)

Of interest seems to be the fact that the interviewed men, when asked about an ideal man, advocated appropriate behaviour on the part of men towards women. An ideal man was described as caring towards his family, respectful towards his wife, and generally as a loving, but skilful, diligent and capable person.

On the other hand, an ideal woman was depicted according to the stereotyped image of a housewife: caring for the family, bringing up children, being able to cook and work hard. In addition, a woman "has to tolerate the things which are exclusively masculine" (Vaclav) and "make no reproaches" (Joseph). The interviewed men in the fourth aspect constructed their masculinities in contrast to the femininities of their mothers and wives. Nevertheless, their depiction of ideal men as loving people who care about the family evokes a Central European Biedermeier tradition and we may think of this feature as a part of the hegemonic masculinity of the time.

3.2.5 The Fifth Aspect "No, I did not work in the kitchen, no. Only outside." (Petr): the relationship to the division of gender roles 
This aspect depicts not only the strict division of gender roles during the period of the participants' childhood and youth which they frequently referred to but also allows us to think about the participants' masculinities as processes, subjected to change over the course of the $20^{\text {th }}$ century.

This aspect in particular has much to tell us about the value of an oral history interview. While the first four aspects have to do more with the discursive construction of gender, the fifth reflects the way masculinity was performed within a particular story (Peter's story described below). Although during each process of recollection the past and the present have to be reconciled (the same is true of biographies, memoirs, journals etc.), it is chiefly this perspective, meaning social interaction during an oral history interview, which enables us to follow the process of "composure" (Dawson 1994:37) in detail. As suggested by Thomson (2004:300), we "compose" memories which help us feel relatively comfortable with our lives by providing us with a feeling of composure. A story which one can feel comfortable with is often one which relies on a broader cultural understanding, in this case on gender norms generally accepted by and within a society. Some stories are therefore more acceptable for presentation in public than others. In Western culture, to give an example related to our topic, the identity of the hard-working provider is a more comfortable and acceptable position for a man than that of the cuckolded husband (Abrams 2010:68). We can consequently understand why the interviewed men chose to emphasise stories related to their masculine models, work and physical strength. Nevertheless, as argued by Dawson (1994:37), by recounting the stories of the past, the narrators also provide a version of the self that can be lived with in relative psychological comfort. There is also a third aspect - a story recounted within an interview process is constructed in relation to the 
interviewer - in this case to a young female interviewer with in all probability different gender norms from those advocated by the interviewed men.

Oral history (and interviews in general) is particularly important here because it allows us to study how gender is negotiated and produced in social interaction, which is what the interview situation is. Vaclav's account provides an apt illustration of the distribution of gender roles at the time of the respondent's youth:

So I was born in Jihlava. I will begin with that. My father came from a family of 11 children. Six of these were boys and all made their living as craftsmen, tradesmen and so on. And what else? My mother was at home. So it will be easy. My father served his apprenticeship as a butcher in Brno. And he established his business in Jihlava. I was born in Jihlava in 1926. My father worked very hard.

The man was the breadwinner, associated with work and a job, and a woman took care of the household. The other participants talked in a similar way about the strict division between gender roles. Girls fetched nettles (for feeding to the domestic poultry), boys took the cattle out to pasture, mothers cooked, fathers worked in the fields. The division of roles was strictly observed and the participants presented themselves as people interested in respecting such a division. In the following extract, Petr argues about boys' and girls' duties which were, apparently exceptionally, contested by his mother:

Here came the order, mother says: "You go for nettles!" And I said: "That's a job for girls". "No, you have to go, we don't have any." They were somewhere outside, so I had to go. 
The division of gender roles described by the participants reflects the gender order in Czechoslovakia in the 1920s. Although with the birth of Czechoslovakia in 1918, and particularly under the new constitution of 1920, women were given, many years earlier than their counterparts in the majority of western European countries, the right to vote and other civil rights, patriarchal society still limited the influence of women to the household. Drawing on an old Austrian law of 1811, the Czechoslovak civil code assigned all power in marriage and in the family to men. The man was the head of the family, while the woman had to look after the household following his directions (Klabouch 1962). A woman's social status continued to be determined by that of her father, or if she was married, by that of her husband. In spite of the activities of women's organisations created after the birth of Czechoslovakia, the distribution of power between men and women remained almost unchanged throughout the entire First Czechoslovak Republic and any process of equalisation even slowed down during the 1930s when, due to the rise of Nazism and the ongoing Depression, individual rights became less pressing than the rights of the family (Garber 1985; Feinberg 2006).

A strict division of gender roles had been challenged, however, during the participants' lives, as reflected in several comments by the participants. Asked about the ideal husband, Petr recounted:

So the ideal husband should, when he comes from work, help his wife. In the kitchen, for example, instead of lying down on the sofa and such. And she has to cook, sew, wash and iron. And still keeps going to work ... If I was at home on Saturday the floor would be washed ... so I washed the floor for her, so that she had a clean house. And she praised me for that, you see? I did it for her ... so everybody was satisfied. And then, my brother-in-law came, a teacher I told you 
about. He and my sister. And she tells him: 'You see that? Look! Petr, how he is helping his wife! He's washing the floor!' 'What are you talking about? How dare you compare me to Petr?' And that was what he said. (recounted in a complaining tone).

In his account Petr explained that one of the activities of an ideal man should be to help his wife around the house. He presents this help as natural for all men and as something that every man should do. In this respect, Petr argues for a different masculine pattern, distinct from the breadwinner model of his father's generation, who were excluded from household work. It is obvious, however, that Petr was not thinking about taking responsibility for the household, but only talking about help worthy of approval.

Petr emphasised his praiseworthy attitude by adding the story of his brother-in-law's arrival, complaining, in his final words, to the interviewer. Washing the floor is said to be natural, but in fact is presented as something unusual, emphasised by the fact that because of his willingness to help, Petr looked ridiculous to his brother-in-law. Expecting perhaps the approval of his female listener, Petr distanced himself from the usual attitudes of men of his generation.

This point demonstrates how masculinity can be negotiated in the interview process on the level of different models of masculinity. While such activities by men as washing the floor were impossible in the interviewee's youth (theme one and two in this article), as they were not part of the male sphere and were viewed as humiliating for "true" men, in the participants' adult lives such behaviour was already possible. With regard to Petr's account, it can be assumed that even if some men considered these kinds of activities as unworthy, women, at least, welcomed such help. Petr's sister - by her exclamation: Did you see that? Look! Petr, how he is helping 
his wife! - indicated that she wished her husband would wash the floor for her too. And finally, there is a current masculinity of a new man who is able to share responsibilities in the household and it is in this context that Petr said: "And that was what he said." By complaining to the female interviewer, he in all probability took into consideration the fact that for men today these activities are not unusual and not considered humiliating at all.

Negotiation on the level of the multiple masculine models available to the participants over the course of their lives led, however, to a contradiction. On the one hand, they expressed their relationship to the hegemonic masculine models available in the period of their youth (what a man should do and how a man should behave) and positioned themselves as true men according to these models; on the other hand they also negotiated their masculinities in relation to new masculine models, contradictory to the models of their youth. As was stated in our discussion of the first aspect, hard-working fathers were sources of admiration for their sons, serving as true models of masculinities. On the other hand, the participants make it clear that they also distance themselves from the masculine models of their fathers. In the following extract, despite a certain degree of esteem felt towards his hard-working father, Vaclav also expresses a serious reservation:

My regret is that my father was so focused on his work. He worked very hard in the right sense of the word. I regret this, but on the other hand, it is stupid to be angry with him for that. But I could see that the sense of his life was this.

Apparently, Vaclav wants to say that his own sense of life already differed from that of his father. The way he constructs his masculinity was also different from his father's, a point which is confirmed later in his discussion. 
Although his ideal man should be healthy and heterosexual, he should not show off as boys usually do, or be one of those who struggle to achieve a position either.

The fifth aspect is notable for the participants' negotiation of their masculinities on the level of the various masculine models available to them during their lifetime. Although they expressed their adherence to the masculine models of their youth, they also described these models as already unsustainable, not completely corresponding to their own vision of true masculinity.

\section{Discussion and conclusion}

The aim of this article was to examine the identity construction process of eight older Czech men in their retrospective narratives about the period of their childhood and youth. Although the focus of research was initially on the period of the first half of the $20^{\text {th }}$ century and the ways the masculinity of the day was formatted, the interviews themselves, which extended to cover more or less the entire life stories of the participants, also allowed for a discussion of masculinities not only as single-time situated achievements but also as processes extended over the lifetime of the participants. In this way, the facts contained in the participants' discussions about their childhood, youth and later periods were perceived as mechanisms through which the participants constructed their masculine identity.

The analysis of the elderly men's narratives revealed five aspects related to the formation of their identity. Firstly, their identity was formatted in relation to other men, particularly the fathers and grandfathers who served as masculine models for their sons, in the circumstances of their 
fathers' own hard physical labour. On the other hand, the interviewed men also constructed their identity vis-a-vis the current young generation of boys and emphasised the superior nature of their own masculinity. The second important aspect revealing the construction of their masculinity was a constant referring to work as a determinant of their lives. The need for strength to perform masculine work was particularly highlighted and presented in contrast to feminine work in the household. The participants' identity was consequently constructed as related to physical strength or extending to various sports activities, with an emphasis on excelling both in sporting activities and in their work duties. Their presentation as hardworking, tough and physically powerful men was completed by their gender distinction from women, principally their mothers and wives, although they clearly linked an ideal masculinity to a Central European Biedermeier tradition. Finally, the fifth aspect, demonstrating the relationship of the participants to the division of gender roles, showed that during the interview the participants negotiated their masculine identity in relation to various masculine models available to them during their lifetime.

If the purpose of this article was also to contribute to the debate concerning the nature of Czech gender order after the fall of communism, we have to recall that Czech late socialism is viewed as an era distinguished by a strong retraditionalisation of gender roles (Havelková and OatesIndruchová 2015b:33), by contrast with a brief attempt in the 1950s to deconstruct the traditional gender hierarchy: the ideologically iconic image of a tractor driver was superseded by conservative femininities of helpmates and self-effacing people, which had coexisted with the images of statesocialist superwomen. As the discursive analysis of Oates-Indruchová (2012) claimed, masculinities were affected differently by state socialism, 
which narrowed the possibilities for men to deliberately express their masculinities. The findings of this research confirm these claims in one way while also being in contradiction with them.

Firstly, the identity of the older men in this research is constructed as strongly related to the hegemonic masculine models available in the participants' youth (although this conclusion involves certain reservations and needs to be tested in subsequent research: the fact that the men do not relate to state-socialist masculinities could also be a result of the focus of the interviews on pre-socialist times. In addition, perceiving patterns from one's youth as more positive than those currently available is a typical generational trope).

Such a masculinity is presented as superior, as the ideal not achievable by today's generation of boys. Deploring the state of boys in the present day, older men call for an appreciation of the masculinities of their youth, emphasising their ability to approach the ideal. However, their desire for the identities of hard-working and physically powerful men operating within a strictly divided gender order does not mean that they wanted to return to the conservative gender order of their youth. On the contrary, they constructed their identities as distant from the models of their hard-working and non-caring fathers, advancing more helpful models of masculinities. The narratives of these older men could be seen as confirming that even if the residual patriarchal discourse was in a position to become dominant after the fall of communism (Oates-Indruchová 2015:378), this position was actually subverted by somewhat residual emancipatory discourses arising from the emancipation rhetoric of state socialism in the 1950s.

Secondly, a notable feature is that femininities are constructed in a fairly stable way in the discussion with the older men, based on the model 
which was already current in the $19^{\text {th }}$ century. The role of women as helpmates and hard-working superwomen is emphasised, the assumption here being that serving and caring is women's responsibility, even if the older men themselves attributed a caring role to men as well. By attaching traditional features of femininities to their wives and the younger generation of women, the older men seemed to express their wish to maintain gender differences.

Lastly, the analysis of the older men's narratives demonstrated that these men did find positive masculine scripts with which they could identify. These masculine models came from the period of their youth and were revealed as contrasting with the masculine patterns of later periods (allowing for the reservations mentioned above). Unlike the participants in Vodochodský's study (2008), which dealt with the biographical experiences of men born in the 1940s, which means around the period of the communist takeover of 1948, the men born in the 1920s were able to express their attachment to such positive models, not yet discredited by the communist regime. Moreover, they identified themselves as holders of ideal masculinities, in contrast to subsequent generations.

In conclusion, it can be argued that the social changes which occurred in Czechoslovakia in the $20^{\text {th }}$ century were unprecedented in terms of gender and that the narratives of the men interviewed reflected these changes, particularly as regards their need to construct their stories in relation to the various masculine models available to them over the course of their lives. Although the analysis was performed on an extremely small sample of interviews and its findings are therefore very limited and require testing via subsequent research, it demonstrated that the narratives of older men represent a valuable source, one which can contribute to the 
exploration of identity construction in a temporal perspective, often neglected by sociological research. Whether further generations of men or samples of educated and middle-class older men would recount their stories differently is a question for further research.

\section{References}

Abrams, Lynn. 2010. Oral History Theory. Oxon: Routledge.

Connell, R.W. 1983. Which Way is Up? Essays on Sex, Class and Culture. Sydney: Allen and Unwin.

Connell, R.W. 1995. Masculinities. Berkeley: University of California Press.

Connell, R.W. 2000. The Men and the Boys. Cambridge: Polity.

Connell, R.W. and James W. Messerschmidt. 2005. "Hegemonic masculinity: rethinking the concept." Gender and Society 19, no. 6 (2005): 829-859.

Creswell, John W. 2011. Educational Research: Planning, Conducting, and Evaluating Quantitative and Qualitative Research. Boston: Pearson.

Dawson, Graham. 1994. Soldier Heroes: British Adventure, Empire, and the Imagining of Masculinities. London: Routledge.

Edley, Nigel. 2001. “Analyzing Masculinity: Interpretative Repertoires, Ideological Dilemmas and Subject Positions." in Discourse as Data: A Guide for Analysis, M. Wetherell, S. Taylor and S. Yates (Eds.). London: Sage and Open University, pp. $189-228$

Filipowicz, Marcin and Joanna Królak. 2008. “Západoslovanská otcovství”. in Od patriarchy $k$ tatínkovi. Západoslovanské modely otcovství. M. Filipowicz, J. Królak and A. Zachová (Eds.). Hradec Králové: Gaudeamus, pp. 5-11.

Fivush, Robyn. 2008. "Remembering and reminiscing: How individual lives are constructed in family narratives.” Memory Studies 1, no. 1 (2008): 49-58.

Garver, M. Bruce M. 1985. "Women in the First Czechoslovak Republic." in Women, State, and Party in Eastern Europe. S. L. Wolchik and A. G. Meyer (Eds.). Duke Press Policy Studies, pp. 64-81.

Havelková, Hana and Libora Oates-Indruchová (Eds.). 2014. The Politics of Gender Culture under State Socialism. An Expropriated Voice. London, New York: Routledge. 
Havelková, Hana and Libora Oates-Indruchová. (Eds.). 2015a. Vyvlastněný hlas. Proměny genderové kultury české společnosti 1948-1989. Praha: Sociologické nakladatelství.

Havelková, Hana and Libora Oates-Indruchová. 2015b. „Vyvlastněný hlas: Proměny genderové kultury české společnosti v letech 1948-1989.” in Vyvlastněný hlas. Proměny genderové kultury české společnosti 1948-1989, H. Havelková and L. Oates-Indruchová (Eds.). Praha: Sociologické nakladatelství, pp. 7-41.

Havelková, Hana. 1999. "Women in and after a 'Classless' Society.” in Women and Social Class - International Feminist Perspectives. Ch. Zmroczek and P. Mahony (Eds.). London: Taylor and Francis, pp. 69-84.

Klabouch, Jiří. 1962. Manželství a rodina v minulosti. Praha: Orbis.

Lenderová, Milena; Kopičková, Božena; Maur, Eduard and Jana Burešová (Eds.). 2009. Žena v českých zemích od středověku do 20. století. Praha: Nakladatelství Lidové noviny.

Lenderová, Milena. 2012. „Genderové stereotypy a konstrukt maskulinity ve společenských katechismech.“ in Konstrukce maskulinní identity v minulosti a současnosti. Koncepty, metody, perspektivy. R. Švaříčková Slabáková, J. Kohoutová, R. Pavlíčková and J. Hutečka (Eds.). Praha: Nakladatelství Lidové noviny, pp. 224-238.

Maříková, Hana.2007. "Participace otců v rodině a genderová ne/rovnost: Co se (z)mění, když pečuje (i) otec?” in Sociální nerovnosti v kvalitativním výzkumu. J. Šanderová (Ed.). Praha: ISS UK FSV, pp. 77-93.

Feinberg, Melissa. 2006. Elusive Equality: Gender, Citizenship, and the Limits of Democracy in Czechoslovakia, 1918-1950. Pittsburgh: University of Pittsburgh Press.

Nečasová, Denisa. 2011. Buduj vlast-posiliǐs mirr! Ženské hnutív českých zemích 19451955. Brno: Matice moravská.

Nečasová, Denisa. 2014. “Women’s organizations in the Czech lands, 1948-1989: an historical perspective“ in The Politics of Gender Culture under State Socialism. An Expropriated Voice. H. Havelková and L. Oates-Indruchová (Eds.). London, New York: Routledge, pp. 57-81.

Nečasová, Denisa. 2015. “Oranizace žen v letech 1948-1989 v historické perspektivě.” in Vyvlastněný hlas. Proměny genderové kultury české společnosti 1948-1989. H. 
Havelková and L. Oates-Indruchová (Eds.). Praha: Sociologické nakladatelství, pp. 169-206.

Oates-Indruchová, Libora. 2006. "The void of acceptable masculinity during Czech State Socialism: The case of Radek John's Memento.” Men and Masculinities 8, no. 4 (2006): 428-450.

Oates-Indruchová, Libora. 2012. "The Beauty and the Loser: Cultural representations of

gender in late state socialism." Signs: Journal of Women in Culture and Society 37, no. 2 (2012): 357-383.

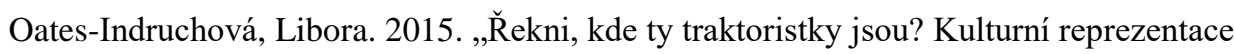
genderu v pozdním socialismu." in Vyvlastněný hlas. Proměny genderové kultury české společnosti 1948-1989. H. Havelková and L. Oates-Indruchová (Eds.). Praha: Sociologické nakladatelství, pp. 393-425.

Portelli, Alessandro. 2004. "What Makes Oral History Different." in The Oral History Reader. R. Perks and A. Thomson (Eds.). London: Routledge, pp. 63-74.

Rokosová, Šárka. 2003. “Administrativní opatření - jedna z forem perzekuce sedláků komunistickým režimem." in Securitas Imperii: sbornik k problematice vztahů čs. komunistického režimu $k$,, vnitřnímu nepř́teli“,J. Táborský, J. (Ed.). Praha: Úřad dokumentace a vyšstřování zločinů komunismu, pp. 147-194.

Šmídová, Iva. 1999. "Men in the Czech Republic: A Few Questions and Thoughts on Studying (Some) Men.” Czech Sociological Review 7, no. 2 (1999): 215-222.

Šmídová, Iva. 2008. Pečovatelská otcovství: Zkušenost a genderové vztahy. Brno: IVRIS. Spector-Mersel, Gabriela. 2014. "Guest editor's introduction, Special issue on Multiplicity and Commonality in Narrative Interpretation. "Narrative Works: Issues, Investigations and Interventions 4, no. 1 (2014): 1-18. https://journals.lib.unb.ca/index.php/nw/article/view/21571/25056 (accessed October 15, 2015).

Summerfield, Penny. 2004. "Culture and Composure: creating narratives of the gendered self in oral history interviews." Cultural and Social History 1, no. 1 (2004): 65-93. Švařiččková-Slabáková, Radmila; Kohoutová, Jitka; Pavličková, Radmila and Jiří Hutečka (Eds.). 2012. Konstrukce maskulinní identity v minulosti a současnosti. Koncepty, metody, perspektivy. Praha: Nakladatelství Lidové noviny.

Thomson, Alistair. 2004. "Anzac memories: putting popular memory theory into practice in 
Australia." in The Oral History Reader. R. Perks and A. Thomson (Eds.). London: Routledge, pp. 300-310.

Tolson, Andrew. 1987. The Limits of Masculinity. London: Routledge.

Tosh, John. 2005. Manliness and Masculinities in Nineteenth-Century Britain: Essays on Gender, Family and Empire. Harlow: Pearson Education.

Vodochodský, Ivan. 2008. Muži - rodina - socialismus: Mužství a generace v biografických vyprávěnich o manželství a otcovství v 70. letech 20. Století, Ph.D. dissertation. Praha: Charles University.

Wagnerová, Alena. 1995. "Emancipace a vlastnictví." Czech Sociological Review 31, no. 1 (1995): 77-84.

Wilkinson, Sue and Celia Kitzinger. 1996. "Theorizing Representing the Other." in Representing the Other: A Feminism \& Psychology Reader, S. Wilkinson and C. Kitzinger (Eds.). London: Sage, pp. 1-32.

${ }^{i}$ This research was supported by GAČR grant 15-02993S entitled "Family Memory and Intergenerational Transmission of Identities". 